\title{
LIQUID - LIQUID EXTRACTION OF CERIUM(IV) FROM SALICYLATE MEDIA USING N-N-OCTYLANILINE IN XYLENE AS AN EXTRACTANT
}

\author{
B. N. KOKARE, A. M. MANDHARE, M. A. ANUSE* \\ Analytical Chemistry Laboratory, Department of Chemistry, \\ Shivaji University, Kolhapur - 416004 , India \\ (Received: March 17, 2009 - Accepted: October 30, 2010)
}

\begin{abstract}
Extraction behaviour of $\mathrm{Ce}(\mathrm{IV})$ from salicylate medium has been studied with the using $\mathrm{N}$ - $n$-octylaniline in xylene as an extractant. Cerium(IV) was completely recovered from the organic phase using $2.0 \mathrm{M}$ hydrochloric acid and determined spectrophotometrically as complex with Arsenazo III. The influence of equilibrium $\mathrm{pH}$, extractant concentration, stripping agents, equilibration time, nature of diluents, and diverse ions on the extraction of Ce(IV) was investigated. The stoichiometry of the extracted species was determined on the basis of slope analysis. The separation of Ce(IV) was carried out from some associated metals like $\mathrm{U}(\mathrm{VI}), \mathrm{Th}(\mathrm{IV}), \mathrm{La}(\mathrm{III}), \mathrm{Y}(\mathrm{III}), \mathrm{Zr}(\mathrm{IV}), \mathrm{Nb}(\mathrm{V}), \mathrm{Gd}(\mathrm{III})$ and $\mathrm{Nd}(\mathrm{III})$. The method presented is simple, reproducible, rapid and has been successfully applied for the determination of $\mathrm{Ce}(\mathrm{IV})$ in synthetic mixture, semiconductor films and monazite sand.
\end{abstract}

Keywords: Solvent extraction, Ce(IV), N-n-octylaniline, sodium salicylate

\section{INTRODUCTION}

Among rare earths, cerium is the most widely distributed element averaging $22 \mathrm{ppm}$ in the earth's crust [1]. Compounds of cerium are used in various fields such as magnetic, catalysts, polishing powder, and ceramic technology. Solvent extraction is reported to be one of the most effective technique to extract cerium(IV) [2]. The main source of cerium are the minerals like monazite (Ce, $\mathrm{La}, \mathrm{Th}, \mathrm{Nd}, \mathrm{Y}) \mathrm{PO}_{4}$ and bastnasite $(\mathrm{Ce}, \mathrm{La}, \mathrm{Y}) \mathrm{CO}_{3} \mathrm{~F}$ in which cerium is coexist with other rare earth (RE) elements.

Anumber of extractants such as di-(-2-ethylhexyl)2-ethylhexylphosphonate (DEHEHP) [2-4], cyanex 923 [5-8], lueco xylene cyanol FF [9], 2-ethylhexyl hydrogen 2-ethylhexyl phosphonate (KSM-17) [10], N, N'-Dimethyl-N,N'diphenylpyridine-2, 6-dicarboxyamide (DMDPhPDA) [11], N-phenylbenzo18-crown-6- hydroxamic acid [12], 1-octyl-3-methylimidazolium hexafluorophosphate [13], high molecular weight carboxylic acids [14], $\mathrm{N}$ - phenyl - (1,2-methanofullerene $\left.\mathrm{C}_{60}\right)$ 61-formohydroxamic acid [15], tri-nbutyl phosphate (TBP) [16], tridodecylamine (TDA), 1-[thenoyl-(2)]-3-3-3trifluoroacetone (HTTA), di (2-ethylhexyl) phosphoric acid (HDEHP) and tricaprylmethylammonium chloride (TCMA) [17], calyx [4] resorcinarene$\mathrm{N}$-fenil-acetohydroxamic acid [18], have been used for the extraction and separation of Ce(IV). However, these methods have limitations such as interference of different ions, emulsion formation, co-extraction, and use of high reagent concentrations.

In the present study the extraction of $\mathrm{Ce}(\mathrm{IV})$ was carried out from weak organic acid media, sodium salicylate, instead of mineral acids such as $\mathrm{HCl}$, $\mathrm{H}_{2} \mathrm{SO}_{4}, \mathrm{HNO}_{3}$ and $\mathrm{HClO}$. The advantage of organic acid over mineral acid is the facility to control the concentration of complexing ligand, the ease of adjustment of $\mathrm{pH}$ due to wide difference in $\mathrm{pH}$ at which various metals form anionic complexes with high stability. The method also becomes environmental friendly. N-n-octylaniline, a secondary amine has been explored as an extractant for Ce(IV) in salicylate media. N-n-octylaniline has its potential advantages with respect to low cost, completely miscible with diluents, low aqueous solubility and high purity.

The present work deals with a study of the extraction of cerium(IV) and its separation from some commonly associated metal ions, such as U(VI), Th(IV), $\mathrm{Nb}(\mathrm{V}), \mathrm{Zr}(\mathrm{IV}), \mathrm{Y}(\mathrm{III}), \mathrm{Nd}(\mathrm{III}), \mathrm{La}(\mathrm{III})$, and $\mathrm{Gd}(\mathrm{III})$ from salicylate media with N-n-octylaniline. The developed method was applied for the recovery of cerium(IV) from synthetic mixtures, semiconducting film and monazite sand.

\section{EXPERIMENTAL}

\section{Apparatus}

An Elico digital spectrophotometer model SL -171 with $1 \mathrm{~cm}$ quartz cells was used for absorbance measurements. $\mathrm{pH}$ measurements were carried out using an Elico digital $\mathrm{pH}$ meter model LI-120
The stock solution of Ce(IV) was prepared by dissolving $4.257 \mathrm{~g}$ of Cerric ammonium sulphate in one liter water containing $2 \mathrm{~mL}$ of concentrated sulphuric acid. The solution was standardized titrimetrically [19]. The working solution was prepared by appropriate dilution of the stock solution with distilled water.

\section{Arsenazo III}

Arsenazo III (S.D.Fine Chemicals) was prepared as a $0.05 \%$ aqueous solution for the spectrophotometric determination of Ce(IV).

\section{N-n-octylaniline}

The extractant N-n-octylaniline was prepared by the method of Gardland et al [20] and its solutions were prepared in xylene.

All other chemicals used in this work were of AR grade. Double distilled water was used throughout the procedure.

\section{General extraction and determination procedure for Cerium(IV)}

An aliquot of $50 \mu \mathrm{g} C \mathrm{Ce}(\mathrm{IV})$ solution was mixed with a sufficient quantity of sodium salicylate $(0.200 \mathrm{~g})$ to make its concentration $0.05 \mathrm{M}$ in a total volume of $25 \mathrm{~mL}$ of the solution. The $\mathrm{pH}$ of the aqueous solution was adjusted to 8.5 with dilute hydrochloric acid and sodium hydroxide solution. The solution was then transferred to a $125 \mathrm{~mL}$ separating funnel and shaken with $10 \mathrm{~mL}$ of 0.3 $\mathrm{M} \mathrm{N}$ - $n$-octylaniline in xylene for $5 \mathrm{~min}$. After separating the two phases, the aqueous phase was discarded and the organic phase was stripped with three 10 $\mathrm{mL}$ portions of $2 \mathrm{M}$ hydrochloric acid solution. The stripped aqueous phase was equilibrated with $5 \mathrm{~mL}$ of xylene to remove the traces of dissolved amine and evaporated to moist dryness. The slightly acidic solution was transferred to a $25 \mathrm{~mL}$ volumetric flask followed by $2 \mathrm{~mL}$ of acetate buffer solution ( $\mathrm{pH}$ 2.6) and $2 \mathrm{~mL}$ of $0.05 \%$ Arsenazo III, diluted to the mark and Ce(IV) was determined spectrophotometrically [21] with Arsenazo III at $660 \mathrm{~nm}$ against the reagent blank in the reference cell. The amount of Ce(IV) in the solution was calculated from the calibration curve.

\section{RESULTS AND DISCUSSION}

\section{Effect of $\mathbf{p H}$}

The effect of $\mathrm{pH}$ on the extraction of $\mathrm{Ce}(\mathrm{IV})$ with $0.13 \mathrm{M} \mathrm{N}-n$-octylaniline in xylene was studied. The percentage extraction of $\mathrm{Ce}(\mathrm{IV})$ increased with the increase in $\mathrm{pH}$ of the aqueous phase up to $\mathrm{pH} 9.0$ and after that decreased. This shows that the equilibrium in the $\mathrm{pH}$ range 8.0-9.0 is favourable for the formation of ion-pair complex from sodium salicylate media (Fig. 1). Thus the optimum $\mathrm{pH} 8.5$ was selected for efficient extraction of $\mathrm{Ce}(\mathrm{IV})$. 


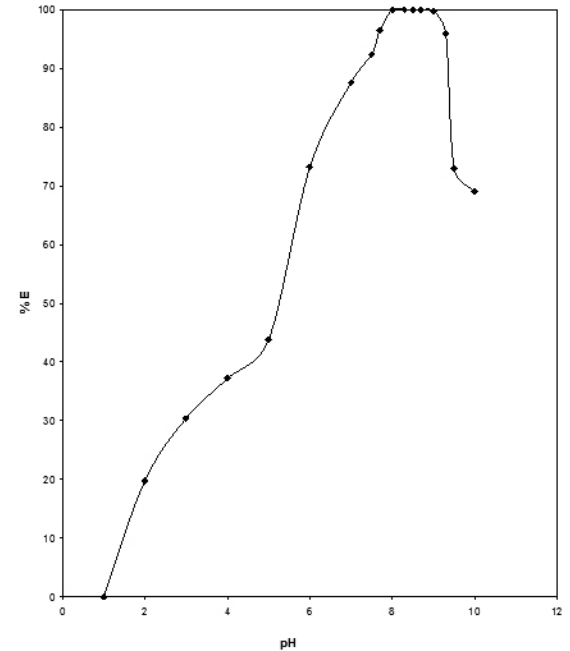

Fig 1. Extraction behaviour of $\mathrm{Ce}(\mathrm{IV})$ as a function of $\mathrm{pH}$ from $0.05 \mathrm{M}$ sodium salicylate with $0.13 \mathrm{M} \mathrm{N}$ - $n$-octylaniline. $(\mathrm{Ce}(\mathrm{IV})=50 \mu \mathrm{g})$

\section{Effect of reagent concentration}

The concentration of $\mathrm{N}-n$-octylaniline in xylene was studied by extracting a fixed amount of $\mathrm{Ce}$ (IV) with varying amount of $\mathrm{N}$ - $n$-octylaniline at the $\mathrm{pH}$ 8.5. It was found that $10 \mathrm{~mL}$ solution of $0.13 \mathrm{M} \mathrm{N}-n$-octylaniline in xylene was quite needed for the complete extraction of $\mathrm{Ce}$ (IV) (Table 1). However lower concentration of $\mathrm{N}-n$-octylaniline reduces the percentage extraction while an excess of reagent, there was no adverse effect on extraction.

Table 1. Effect of $\mathrm{N}-n$-octylaniline Concentrations on the Extraction of Ce(IV)

\begin{tabular}{|ccc|}
\hline N-n-octylaniline, (M) & $\begin{array}{c}\text { Percentage extraction, } \\
(\% \mathrm{E})\end{array}$ & Distribution ratio,(D) \\
\hline 0.00 & 0.00 & 0.00 \\
0.0022 & 52.3 & 4.8 \\
0.0044 & 66.6 & 7.7 \\
0.022 & 75.4 & 9.3 \\
0.031 & 78.7 & 10.2 \\
0.043 & 80.3 & 41.3 \\
0.087 & 94.3 & 77.0 \\
0.11 & 100.0 & $\infty$ \\
0.13 & 100.0 & $\infty$ \\
0.17 & 100.0 & $\infty$ \\
0.22 & 100.0 & $\infty$ \\
0.30 & 100.0 & $\infty$ \\
0.43 & 100.0 & $\infty$ \\
0.65 & 100.0 & $\infty$ \\
\hline
\end{tabular}

$\mathrm{Ce}(\mathrm{IV})=50 \mu \mathrm{g}, \quad \mathrm{pH}=8.5$, Aq: Org ratio $=25: 10$, Sodium salicylate $=$ $0.05 \mathrm{M}$, $\min$.

Strippant $=2.0 \mathrm{M}$ Hydrochloric acid $(3 \times 10 \mathrm{~mL}), \quad$ Equilibrium time $=5$

\section{Effect of weak organic acid concentration}

The extraction of $\mathrm{Ce}$ (IV) from $0.01-0.1 \mathrm{M}$ of various weak organic acids were studied with $0.13 \mathrm{M} \mathrm{N}-n$-octylaniline in xylene (Table 2). The extraction of $\mathrm{Ce}$ (IV) was found to be quantitative in the range of $0.04 \mathrm{M}-0.07 \mathrm{M}$ sodium salicylate. Hence, further studies were carried out using $0.05 \mathrm{M}$ of sodium salicylate as the aqueous phase. While the extraction of Ce(IV) was found to be incomplete in sodium succinate, sodium malonate and sodium citrate media.
Table 2. Extraction of $\mathrm{Ce}(\mathrm{IV})$ as a function of Weak Organic Acid Concentrations.

\begin{tabular}{|cccccccccc|}
\hline \multirow{2}{*}{$\begin{array}{c}\text { Acid } \\
\text { Concen- } \\
\text { tration,(M) }\end{array}$} & \multicolumn{2}{c}{$\begin{array}{c}\text { Sodium } \\
\text { salicylate }\end{array}$} & \multicolumn{2}{c}{$\begin{array}{c}\text { Sodium } \\
\text { succinate }\end{array}$} & \multicolumn{2}{c|}{$\begin{array}{c}\text { Sodium } \\
\text { malonate }\end{array}$} & \multicolumn{2}{c|}{$\begin{array}{c}\text { Sodium } \\
\text { citrate }\end{array}$} \\
\cline { 2 - 11 } & E & D & $\%$ E & D & $\%$ E & D & $\%$ E & D \\
\hline 0.01 & 35.6 & 1.4 & 39.4 & 1.6 & 15.4 & 0.5 & 30.5 & 1.1 \\
0.02 & 51.3 & 2.6 & 53.3 & 2.9 & 25.8 & 0.9 & 25.4 & 0.9 \\
0.03 & 92.5 & 10.8 & 69.3 & 5.6 & 32.5 & 1.2 & 12.1 & 0.3 \\
0.04 & 100.0 & $\infty$ & 76.4 & 8.1 & 40.0 & 1.7 & 5.7 & 0.2 \\
0.05 & 100.0 & $\infty$ & 87.9 & 18.1 & 50.8 & 2.6 & - & - \\
0.06 & 100.0 & $\infty$ & 61.7 & 4.0 & 57.4 & 3.4 & - & - \\
0.07 & 100.0 & $\infty$ & 58.9 & 3.6 & 61.5 & 4.0 & - & - \\
0.08 & 78.7 & 9.2 & 54.8 & 3.0 & 48.1 & 2.3 & - & - \\
0.09 & 73.2 & 6.8 & 49.0 & 2.4 & 45.2 & 2.1 & - & - \\
0.1 & 60.1 & 3.8 & 40.0 & 1.7 & 31.0 & 1.1 & - & - \\
\hline
\end{tabular}

$\mathrm{Ce}(\mathrm{IV})=50 \mu \mathrm{g}, \mathrm{pH}=8.5$, Aq: Org ratio $=25: 10, \mathrm{~N}-n$-octylaniline $=10$ $\mathrm{mL} 0.13 \mathrm{M}$ in

xylene, Strippant $=2.0 \mathrm{M}$ Hydrochloric acid $(3 \times 10 \mathrm{~mL}), \quad$ Equilibrium time $=5 \mathrm{~min}$

\section{Effect of solvents}

Extraction with high molecular weight amine extractant depends upon the nature of diluent. In order to study the role of diluents during extraction of $\mathrm{Ce}(\mathrm{IV})$, various organic solvents such as xylene, benzene, toluene, methyl iso-butyl ketone (MIBK), kerosene, chloroform, 1, 2-dichloethane, carbon tetrachloride were examined as diluents for $\mathrm{N}$ - $n$-octylaniline (Table 3). Quantitative extraction of Ce(IV) was possible using xylene as a adequate solvent for $\mathrm{N}-n$-octylaniline. Hence $0.13 \mathrm{M} \mathrm{N}$ - $n$-octylaniline in xylene was used in throughout the studies. The non-polar organic solvents with a low dielectric constant had better extractability for Ce(IV). However, no particular reason can be given for the comparatively lower ' $\mathrm{D}$ ' values for Ce(IV) using kerosene and carbon tetrachloride as an diluents.

Table 3. Effect of Diluents on Extraction of Ce(IV).

\begin{tabular}{|cccc|}
\hline Diluent & $\begin{array}{c}\text { Dielectric } \\
\text { constant, } \varepsilon\end{array}$ & $\begin{array}{c}\text { Percentage } \\
\text { extraction, } \\
(\% \mathrm{E})\end{array}$ & $\begin{array}{c}\text { Distribution } \\
\text { ratio, (D) }\end{array}$ \\
\hline Benzene & 2.28 & 75.8 & 7.8 \\
Toluene & 2.38 & 97.7 & 102.1 \\
Xylene & 2.30 & 100.0. & $\infty$ \\
Kerosene & 1.80 & 38.2 & 1.5 \\
Carbon tetrachloride & 2.24 & 50.5 & 2.5 \\
Chloroform & 4.40 & 89.9 & 22.1 \\
Amyl alcohol & 13.90 & 72.0 & 6.5 \\
1,2-Dichloroethane & 10.5 & 85.1 & 14.2 \\
MIBK & 13.11 & 79.4 & 93.7 \\
$n$-Butanol & 17.80 & 78.3 & 9.0 \\
\hline
\end{tabular}

$\mathrm{Ce}(\mathrm{IV})=50 \mu \mathrm{g}, \mathrm{pH}=8.5$, Aq: Org ratio $=25: 10$, Sodium salicylate $=$ $0.05 \mathrm{M}$,

Strippant $=2.0 \mathrm{M}$ Hydrochloric acid $(3 \times 10 \mathrm{~mL}), \quad$ Equilibrium time $=5$ $\min , \mathrm{N}$-n-octylaniline $=10 \mathrm{~mL} 0.13 \mathrm{M}$ in xylene.

\section{Nature of extracted species}

The stoichiometry of the complex species was determined by using log D- $\log \mathrm{C}$ plots. A plot of the distribution ratio $\log \mathrm{D}$ versus the $\log \mathrm{C}$ of the salicylate concentration at a fixed $\mathrm{pH} 6.0$ and 10.0 and $0.13 \mathrm{M} \mathrm{N}$ - $n$-octylaniline concentrations gave a slope of 1.86 and 2.12 respectively (Fig. 2). A graph of $\log \mathrm{D}_{[\mathrm{Ce}(\mathrm{IV})]}$ versus $\log \mathrm{C}_{\text {[N-n-octylaniline }}$ at fixed salicylate concentration and $\mathrm{pH} 6.0$ and 10.0 gave a slope of 1.73 and 1.94 respectively (Fig. 3). This indicates a molar ratio of 1:2 Ce(IV) with respect to salicylate and that of $\mathrm{N}-n$-octylaniline is also 1:2. Thus the extracted species was calculated to be an ion association complex with the probable composition 1:2:2 (metal: acid: extractant). The probable mechanism of extracted species as fallows, 


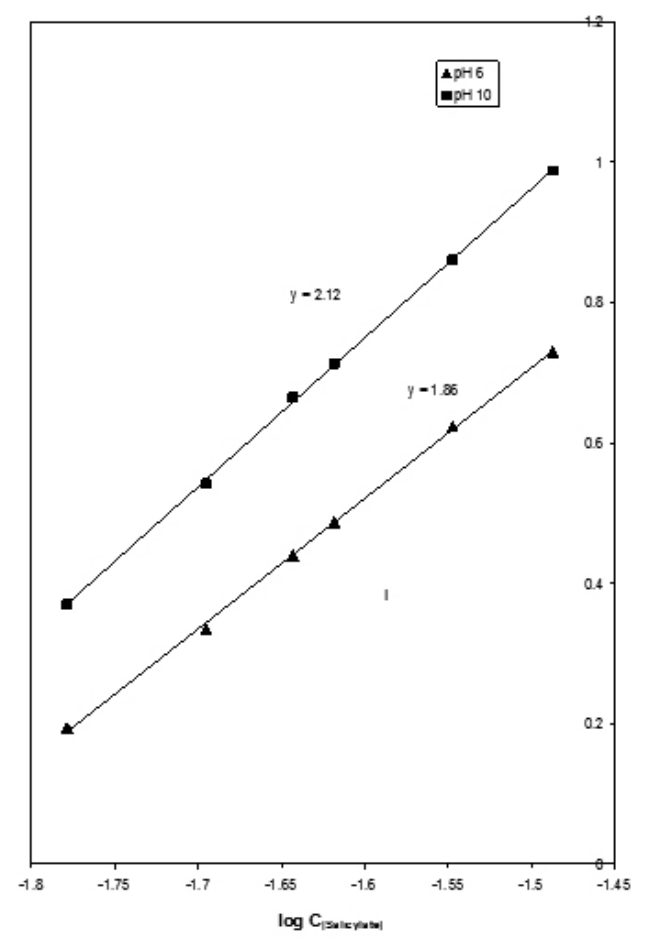

Fig 2. Log- $\log$ plot of $\log \mathrm{D}_{\text {[Ce(IV)] }}$ against $\log \mathrm{C}_{\text {[sodium salicylate] }}$ at fixed N- $n$ octylaniline concentration $(0.13 \mathrm{M})$.

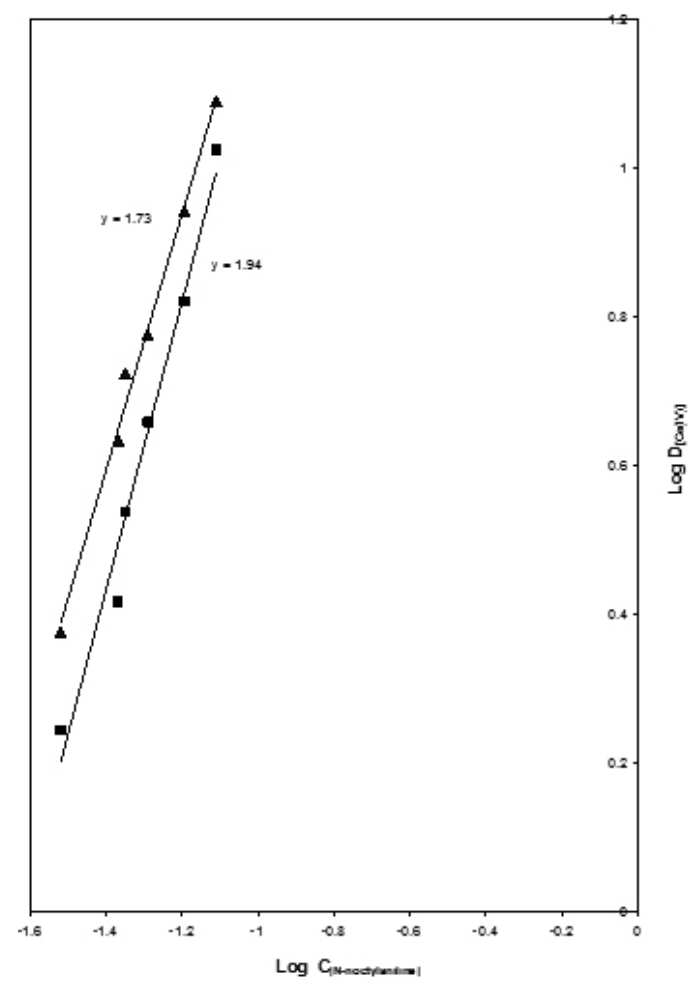

Fig 3. Log-log plot of $\log \mathrm{D}_{[\mathrm{Ce}(\mathrm{IV})]}$ against $\log \mathrm{C}_{[\mathrm{N}}$ salicylate concentration $(0.05 \mathrm{M})$.

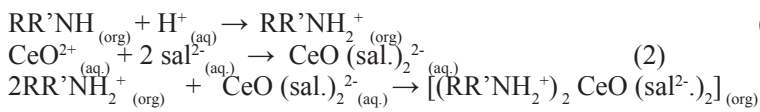
at fixed sodium

\section{Effect of stripping agent}

Stripping is the reverse of the extraction, so it should be promoted by those factors that affect the extraction negatively such as acidic and salt media. Alkalies were unsuccessful because the anion complex adhered in the organic medium under these conditions. The stripping percentage was calculated relative to the initial amount of $\mathrm{Ce}$ (IV) in the pregnant organic solution. Mineral acids such as hydrochloric acid, nitric acid, perchloric acid sulphuric acid and acetic acid were used as stripping agents for back extraction of Ce(IV) from the organic phase. The results are summarized in table 4. It was observed that quantitative recovery was achieved with three $10 \mathrm{~mL}$ portion of 1.5 to 2.5 $\mathrm{M}$ hydrochloric acid as a stripping agent. In practice, three $10 \mathrm{~mL}$ portion of 2.0 $\mathrm{M}$ hydrochloric acid was found to be suitable stripping agent. In other mineral acids back extraction is not successful because it might be due to no complete dissociation of ion-pair complex.

The stripping of $\mathrm{Ce}(\mathrm{IV})$ with mineral acid such as $\mathrm{HCl}$ took place accordingly the following equation (4). $\underset{(4)}{\left[\left(\mathrm{RR}^{\prime} \mathrm{NH}_{2}^{+}\right)_{2}\right.} \underset{\mathrm{CeOCl}_{2}}{\mathrm{CeO}} \underset{\left.\left(\mathrm{sal}^{2-} .\right)_{2}\right]_{\text {org }}}{[}+2 \mathrm{HCl}=2 \mathrm{RR}^{\prime} \mathrm{NH}+2 \mathrm{C}_{6} \mathrm{H}_{4}(\mathrm{OH}) \mathrm{COOH}+$

Table 4. Effect of Stripping agent on Recovery of Ce(IV)

\begin{tabular}{|cccccc|}
\hline $\begin{array}{c}\text { Molarity, } \\
(\mathrm{M})\end{array}$ & $\begin{array}{c}\mathrm{HCl} \mathrm{Re}- \\
\text { covery,\% }\end{array}$ & $\begin{array}{c}\mathrm{HClO}_{4} \\
\text { Recov- } \\
\text { ery,\% }\end{array}$ & $\begin{array}{c}\mathrm{HNO}_{3} \\
\text { Recov- } \\
\text { ery,\% }\end{array}$ & $\begin{array}{c}\mathrm{CH}_{3} \mathrm{COOH} \\
\text { Recov- } \\
\text { ery,\% }\end{array}$ & $\begin{array}{c}\mathrm{H}_{2} \mathrm{SO}_{4} \\
\text { Recov- } \\
\text { ery,\% }\end{array}$ \\
\hline 0.1 & 78.6 & 67.4 & 66.0 & 67.6 & 54.4 \\
0.5 & 80.6 & 61.8 & 88.2 & 80.1 & 63.8 \\
1.0 & 96.2 & 55.0 & 71.3 & 80.1 & 79.1 \\
1.5 & 100.0 & 49.4 & 66.3 & 69.4 & 91.7 \\
2.0 & 100.0 & 45.0 & 58.0 & 67.0 & 90.0 \\
2.5 & 100.0 & 40.6 & 53.9 & 66.7 & 82.1 \\
3.0 & 84.7 & 34.4 & 53.9 & 64.2 & 74.7 \\
3.5 & 78.9 & 27.4 & 40.6 & 63.3 & 67.7 \\
4.0 & 66.8 & 25.3 & 38.5 & 59.0 & 57.7 \\
5.0 & 62.7 & 18.5 & 34.6 & 54.5 & 43.3 \\
\hline
\end{tabular}

Strippant Recovery, \%

1) Water 7.9

2) Acetate buffer $(\mathrm{pH}=3.42) 89.5$

$(\mathrm{pH}=5.57) 85.0$

$\mathrm{Ce}(\mathrm{IV})=50 \mu \mathrm{g}, \mathrm{pH}=8.5$, Aq: Org ratio $=25: 10$, Sodium salicylate $=$ $0.05 \mathrm{M}$,

Equilibrium time $=5 \mathrm{~min}, \mathrm{~N}$-n-octylaniline $=10 \mathrm{~mL} 0.13 \mathrm{M}$ in xylene.

\section{Period of equilibration}

The extraction of $\mathrm{Ce}$ (IV) was examined for various periods of equilibration from 0.16 to $20 \mathrm{~min}$. with $\mathrm{N}$ - $n$-octylaniline. Quantitative extraction of $\mathrm{Ce}$ (IV) was found within $4 \mathrm{~min}$. There was no adverse effect on the extraction yield up to $20 \mathrm{~min}$. with either of the extractant. Hence $5 \mathrm{~min}$. period for equilibrium was recommended in order to ensure the complete extraction of metal ion.

\section{Effect of aqueous to organic volume ratio}

The extraction of $\mathrm{Ce}(\mathrm{IV})$ was carried out in different aqueous to organic volume ratios in the range $300-10 \mathrm{~mL}$ of $0.05 \mathrm{M}$ aqueous sodium salicylate medium with $10 \mathrm{~mL} 0.13 \mathrm{M} \mathrm{N}$ - $n$-octylaniline in xylene have been studied. There was sharp increase in the separation efficiency and distribution ratio of $\mathrm{Ce}(\mathrm{IV})$, when phase ratio $\mathrm{A} / \mathrm{O}$ varied from $20: 1$ to $3: 1$. The recommended procedure the phase ratio is used 2.5: 1 .

\section{Metal loading capacity of extractant}

The influence of the initial Ce(IV) concentration 40-1500 $\mu \mathrm{g}$ on the extraction by $\mathrm{N}-n$-octylaniline in xylene was studied. It was observed that, varying the initial $\mathrm{Ce}(\mathrm{IV})$ concentration in the range of 40-200 $\mu \mathrm{g}$ has no significant influence of $\mathrm{Ce}(\mathrm{IV})$ extraction with the extractant. The maximum loading capacity of $10 \mathrm{~mL} 0.13 \mathrm{M}$ solution of $\mathrm{N}-n$-octylaniline in xylene was found to be $200 \mu \mathrm{g} \mathrm{Ce}(\mathrm{IV})$.

\section{Effect of diverse ions}

The effect of various cations and anions on extraction of Ce(IV) with 0.13 $\mathrm{M} \mathrm{N}-n$-octylaniline in xylene was studied. The tolerance limit was set as the 
amount of foreign ion causing a change $\pm 2 \%$ error in the recovery of Ce(IV) Initially the foreign ion was added to the Ce(IV) solution in large excess, 100 $\mathrm{mg}$ for anions and $25 \mathrm{mg}$ for cations. However, interference due to $\mathrm{V}(\mathrm{V})$ and

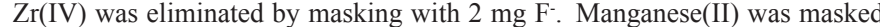
with $5 \mathrm{mg}$ oxalate. The ions such as EDTA, citrate interfere with the extraction of Ce(IV) by the proposed method (Table 5).

Table 5. Effect of Various Diverse Ions.

\begin{tabular}{|ccl|}
\hline $\begin{array}{c}\text { Ratio of ions } \\
\text { Ce(IV): Ions }\end{array}$ & $\begin{array}{c}\text { Tolerance } \\
\text { limit, }(\mathrm{mg})\end{array}$ & Foreign ions \\
\hline $1: 1000$ & 50 & $\begin{array}{l}\text { Bromide, thiourea, salicylate, } \\
\text { nitrate, thiosulphate }\end{array}$ \\
$1: 500$ & 25 & Malonate, acetate, iodide, nitrite \\
$1: 300$ & 15 & Oxalate, thiocyante \\
$1: 100$ & 5 & Fluoride \\
$1: 20$ & 1 & Ascorbate \\
$1: 10$ & 0.5 & Phosphate, tartrate \\
$1: 140$ & 7 & $\mathrm{Ca}^{2+}, \mathrm{Mg}^{2+}$ \\
$1: 100$ & 5 & $\mathrm{Sr}^{2+}, \mathrm{Cr}^{4+}$ \\
$1: 20$ & 1 & $\mathrm{~W}^{6+}, \mathrm{U}^{6+}, \mathrm{Ni}^{2+}$ \\
$1: 10$ & 0.5 & $\mathrm{Cd}^{2+}, \mathrm{Zn}^{2+}, \mathrm{Re}^{7+}, \mathrm{Pd}^{2+}, \mathrm{Mo}^{6+}, \mathrm{Fe}^{2+}$, \\
$1: 6$ & 0.3 & $\mathrm{Sm}^{3+},{ }^{2+} \mathrm{Nd}^{3+},{ }^{\mathrm{c}} \mathrm{Ya}^{3+}, \mathrm{Co}^{2+},{ }^{\mathrm{b}} \mathrm{Mn}^{2+}$ \\
$1: 4$ & 0.2 & $\mathrm{Rh}^{3+}, \mathrm{La}^{3+}, \mathrm{Ti}^{4+}$ \\
\hline
\end{tabular}

$\mathrm{a}=$ masked by $3 \mathrm{mg} \mathrm{F}^{-}, \mathrm{b}=$ masked by $5 \mathrm{mg}$ oxalate, $\mathrm{c}=$ masked by 50 $\mathrm{mg} \mathrm{S} \mathrm{O}_{3}$

Ce(IV) $=50 \mu \mathrm{g}, \quad \mathrm{pH}=8.5$, Aq: Org ratio $=25: 10$, Sodium salicylate $=$ $0.05 \mathrm{M}$, Equilibrium time $=5 \mathrm{~min}$, Reagent $=10 \mathrm{~mL} 0.13 \mathrm{M} \mathrm{N}$-n-octylaniline in xylene, Strippant $=2.0 \mathrm{M}$ Hydrochloric acid $(3 \times 10 \mathrm{~mL})$.

\section{APPLICATIONS}

Separation and determination of cerium(IV) from binary mixture

The separation of Ce(IV) from some commonly associated metal ions like $\mathrm{U}(\mathrm{VI}), \mathrm{Th}(\mathrm{IV}), \mathrm{Ti}(\mathrm{IV}), \mathrm{Nb}(\mathrm{V}), \mathrm{Zr}(\mathrm{IV}), \mathrm{Y}(\mathrm{III}), \mathrm{La}(\mathrm{III}), \mathrm{Nd}(\mathrm{III})$ and $\mathrm{Gd}(\mathrm{III})$ using $\mathrm{N}-n$-octylaniline can be achieved by taking advantage of the difference in the extraction conditions of metal such as $\mathrm{pH}$ of the aqueous phase, reagent concentration and use of masking agent (Table 6).

Table 6. Separation of Ce(IV) from Binary Mixtures.

\begin{tabular}{|ccccc|}
\hline Metal ion & $\begin{array}{c}\text { Metal ion } \\
\text { added, }(\mu \mathrm{g})\end{array}$ & $\begin{array}{c}\text { Average }(\%) \\
\text { Recovery* }\end{array}$ & $\begin{array}{c}\text { Chromogenic } \\
\text { ligand }\end{array}$ & $\begin{array}{c}\text { Reference } \\
\text { number }\end{array}$ \\
\hline Ce (IV) & 50 & 98.3 & Arsenazo III & 21 \\
U(VI) & 50 & 99.4 & PAR & 22 \\
Ce (IV) & 50 & 99.7 & PAR & 22 \\
Nb(V) & 50 & 98.6 & Alizarin & 23 \\
Ce (IV) & 50 & 98.7 & Red S & \\
Zr(IV) & 150 & 98.9 & Arsenazo I & 24 \\
Ce (IV) & 50 & 99.3 & PAR & 22 \\
Gd(III) & 75 & 99.7 & & \\
Ce (IV) & 50 & 98.9 & Arsenazo III & 25 \\
Nd(III) & 60 & 99.8 & Alizarin & 23 \\
Ce (IV) & 50 & 98.6 & Red S & \\
Th(IV) & 50 & 99.8 & & 26 \\
Ce (IV) & 50 & 99.6 & Arsenazo I & 23 \\
Y(III) & 150 & 99.8 & 99.5 & \\
Ce (IV) & 50 & 99.2 & & \\
La(III) & 60 & & &
\end{tabular}

${ }^{\mathrm{a}}$ masked with $0.5 \mathrm{mg}$ tartrate, ${ }^{\mathrm{b}}$ masked with $50 \mathrm{mg}$ thiosulphate .

* Average of six determinations.

Cerium(IV) was separated from $\mathrm{U}(\mathrm{VI})), \mathrm{Nb}(\mathrm{V}), \mathrm{Zr}(\mathrm{IV}), \mathrm{Gd}(\mathrm{III})$ and
$\mathrm{Nd}(\mathrm{III})$ by its extraction with $10 \mathrm{~mL} 0.13 \mathrm{M} \mathrm{N}$ - $n$-octylaniline in xylene from $0.03 \mathrm{M}$ sodium salicylate. Under this condition the added metal ions remained quantitatively in the aqueous phase. The aqueous phase is washed with $5 \mathrm{~mL}$ xylene to remove traces of the reagent. Metal ions from the aqueous phase were determined by standard methods [22-25]. Cerium(IV) from the organic phase was stripped with three $10 \mathrm{~mL}$ portions of $2 \mathrm{M}$ hydrochloric acid and estimated as per the general procedure.

Similarly Ce(IV) was separated from Th(IV) and Y(III) by masking with $0.5 \mathrm{mg}$ tartrate and $50 \mathrm{mg}$ thiosulphate respectively. The masked Th(IV) and Y(III) remained in the aqueous phase quantitatively under the optimum extraction condition of Ce(IV). After demasking of Th(IV) and Y(III) with $5 \mathrm{~mL}$ hydrochloric acid, the solution was evaporated to dryness. They were determined spectrophotometrically with Arsenazo III at $645 \mathrm{~nm}$ [21] and Alizarin Red S [23], respectively.

\section{Determination of $\mathrm{Ce}(\mathrm{IV})$ in synthetic mixture}

The applicability of the method for isolation and determination of Ce(IV) in complex mixtures was studied (Table 7). In the synthetic mixtures, Ce(IV) was extracted under the optimum extraction conditions and quantitatively recovered in all mixtures.

Table 7. Separation of Ce(IV) from Synthetic Mixture.

\begin{tabular}{|ccc|}
\hline Composition of mixture, ( $\mu$ g) & $\begin{array}{c}\text { Average (\%) } \\
\text { Recovery* }\end{array}$ & $\begin{array}{c}\text { Relative } \\
\text { error, (\%) }\end{array}$ \\
\hline $\mathrm{Ce}(\mathrm{IV})$ 50; $\mathrm{U}(\mathrm{VI})$ 50; Th(IV) 50 & 99.3 & 0.7 \\
$\mathrm{Ce}(\mathrm{IV})$ 50; $\mathrm{La}(\mathrm{III})$ 60; Zr(IV) 150 & 99.6 & 0.4 \\
$\mathrm{Ce}(\mathrm{IV})$ 50; Nb(V) 50; Zr(IV) 150 & 99.8 & 0.2 \\
$\mathrm{Ce}(\mathrm{IV})$ 50; $\mathrm{Y}(\mathrm{III})^{\mathrm{b}}$ 150; Nb(V) 50 & 99.2 & 0.8 \\
$\mathrm{Ce}(\mathrm{IV})$ 50; $\mathrm{Nb}(\mathrm{V})$ 50; Gd(III) 75 & 99.5 & 0.5 \\
\hline
\end{tabular}

${ }^{\mathrm{a}}$ masked with $0.5 \mathrm{mg}$ tartrate, ${ }^{\mathrm{b}}$ masked with $50 \mathrm{mg}$ thiosulphate .

* Average of five determinations.

\section{Analysis of cerium(IV) in monazite sand}

About $1.0 \mathrm{~g}$ of monazite sand was dissolved in a mixture of nitric acid and sulphuric acid (1:1). After separating insoluble silica, the solution was diluted to $100 \mathrm{~mL}$ with distilled water. An aliquot of sample solution was subjected to the proposed method for the separation and determination of cerium from uranium and thorium in monazite sand. Uranium(VI) remained quantitatively in the aqueous phase. The interference of thorium(IV) was removed by masking with $0.5 \mathrm{mg}$ tartrate. The amount of cerium obtained was $27.6 \%$ against the standard value of $27.7 \%$ Table 8 .

\section{Determination of cerium(IV) in thin film}

The proposed method is also applicable for determination of $\mathrm{Ce}(\mathrm{IV})$ in thin film $\left[\mathrm{CeO}_{2}\right]$. The amount of $\mathrm{Ce}$ (IV) found in the sample by the proposed method is in good agreement with amount of Ce(IV) taken in $\mu$ g Table 8.

Table 8. Determination of Ce(IV) in Thin Film and Monazite Sand.

\begin{tabular}{|ccc|}
\hline Real sample & $\begin{array}{c}\text { Amount of Ce(IV) } \\
\text { certified value }\end{array}$ & $\begin{array}{c}\text { Amount found by } \\
\text { proposed method* }\end{array}$ \\
\hline Monazite sand & $27.7 \%$ & $27.6 \%$ \\
\hline Thin film material & $39 \mu \mathrm{g}$ & $38.70 \mu \mathrm{g}$ \\
\hline
\end{tabular}

*Average of triplicate analysis

\section{CONCLUSIONS}

The proposed extractive separation method is simple, rapid, selective reproducible and suitable for separation and determination of $\mathrm{Ce}(\mathrm{IV})$ from associated metal ions and synthetic mixtures. The method is applicable to the extraction and estimation of cerium from monazite sand and semiconducting films. The extraction mechanism corresponds to an anion exchange, in which a complex of stoichiometric formula $\left[\left(\mathrm{RR}^{\prime} \mathrm{NH}_{2}^{+}\right)_{2}\left[\mathrm{CeO}(\mathrm{sal})_{2}\right]^{2-}\right]_{\text {org }}$ is formed in the organic phase. This was determined by the conventional slope analysis method. It is free from interference of a large number of foreign ions. The solvent like xylene was non-toxic and suitable for proposed method. N- $n$ octylaniline can be synthesized at low cost, with high yield and best purity. 


\section{ACKNOWLEDGEMENTS}

Mr. B. N. Kokare is grateful to University Grants Commission, New Delhi for providing financial assistance. Authors thanks to UGC-SAP and DST-FIST for financial support for this research work.

\section{REFERENCES}

[1] S. A. Abbasi, Intern. J. Environ. Anal. Chem. 34,181, (1998).

[2] J. Zhao, S. Meng, D. Li, Solvent Extr. Ion. Exch. 22 (3), 429, (2004).

[3] J. Zhao, S. Meng, D. Li, Solvent Extr. Ion. Exch. 22 (5), 813, (2004).

[4] J. Zhao, Y. Zuo, D. Li, S. Liu, J. Alloys Compd. 374 (1-2), 438. (2004).

[5] W. Liao, G. Yu, D. Li, Solvent Extr. Ion. Exch. 19 (2), 243, (2001).

[6] B. Gupta, P. Malik, A. Deep, Solvent Extr. Ion. Exch. 21,239, (2003).

[7] B. Gupta, P. Malik, A. Deep, J. Radioanal. Nucl.Chem.251 (3), 451, (2002).

[8] W. P. Liao, G. H. Yu, D. Q. Li, Acta Metallurgica Sinica 14 (1), 21,21, (2001).

[9] H. D. Revansiddappa, T. N. Kiran Kumar, Anal. Sci. 18, 1275, (2002).

[10] P. S. Dhami, N. L. Dudwadkar, P. V. Achuthan, U. Jambunathan, P. K. Dey, Sep. Sci. Technol. 39, 3143, (2004)

[11] A. Shimada, T. Yaita, H. Narita, S. Tachimori, K. Okuno, Solvent Extr. Ion. Exch. 22, 147, (2004).

[12] Y. K. Agrawal, S. B. Vora, G. Shah, Indian J. Chem. 44A (3), 497, (2005).
[13] Y.Zuo,Y.Liu, J.Chen, D.Q. Li, Industrial Engineering Chem. Research 47 (7), 2349, (2008)

[14] D. K. Singh, H. Singh, J. N. Mathur, Hydrometallurgy 81, 174, (2006).

[15] Y. K. Agrawal, Fullerenes, Nanotubes, Carbon Nanostructures, 12 (3), $545,(2004)$.

[16] L. Jelinek, Y.Wei, M. Kumagai, Solvent Extr. Ion. Exch. 24, 765, (2006)

[17] F. H. El-Sweify, M. M. Kamel, J. Radioanal. Nucl.Chem. 207 (2), 369, (1996).

[18] V. K. Jain, S. G. Pillai, P. H. Kanaiya, J. Braz. Chem. Soc. 17 (7), 1316, (2006).

[19] A. I. Vogel, A Textbook of Quantitative Inorganic Analysis, $3^{\text {rd }}$ edition, Longman, London, 1962, PP.1961.

[20] Z. G. Gardlund, R. J. Curtis and G. W. Smith, Liq. Crystals Ordered Flu, 2, 54, (1973).

[21] Z. Marckzenko, Spectrophotometric Determination of Elements, $1^{\text {st }}$ edition, Ellis Horwood Limited, Chichester, 1976.

[22] H. A. Flaschka, A. J. Barnard Jr, Chelates in Analytical Chemistry, Volume 4, Marcel Dekker Inc. New York, 1972.

[23] E. B. Sandell, Colorimetric Determination of Traces of Metals, $3^{\text {rd }} \mathrm{ed}$, Interscience Publisher Inc., New York, 1965.

[24] M. R. Shivade and V. M. Shinde, Fresenius Z. Anal. Chem. 317, 792, (1984).

[25] K. N. Munshi and A. K. Dey, Anal. Chem., 36, 2003, 1964).

[26] S. Shibata, F.Takeuchi and T. Matsumae, Anal. Chim. Acta, 21, 177, (1959). 